\title{
HUBUNGAN HUKUM ANTARA PASIEN DENGAN TENAGA MEDIS (DOKTER) DALAM PELAYANAN KESEHATAN
}

Oleh :

\author{
Hj. Ukilah Supriyatin, S.H., M.H. ${ }^{*}$ \\ ukilahsupriyatin@yahoo.com
}

\begin{abstract}
Communities who are concentrated on public health or health services are Medical Personnel (doctors) to know their rights and obligations in order to provide health assistance to the community.

What is the legal relationship between patients and medical personnel (doctors) in health services? The research objective is to find out and study the legal relationship between patients and medical personnel (doctors) in providing health services. The usefulness of research is expected to increase knowledge, especially in relation to the material of Health Law, Agreement Law, and Consumer Protection Law.

The research method is by using a normative juridical approach that is examining various norms of rules or regulations that relate to the object of research on legal relations between patients and medical personnel (doctors) in health services.

The doctor's relationship with the patient arises because of the agreement to do something for the doctor to be willing to try according to his ability (to the maximum extent possible) to fulfill the agreement that is to treat and try in accordance with the standards of the medical profession while the patient is obliged to provide compensation.

Strictly speaking, the relationship between the doctor and the patient is needed because the existence of an agreement has resulted in the attainment of a covenant that creates mutual rights and obligations, so that the agreement has binding strength meaning that it has legal force that is obeyed by both parties.
\end{abstract}

Keywords: Patients, Medical Personnel (doctors), Legal relations.

\section{ABSTRAK}

Masyarakat yang konsent dengan kesehatan masyarakat atau pelayanan kesehatan yaitu Tenaga Medis (dokter) agar mengetahui hak dan kewajibannya dalam rangka memberikan bantuan kesehatan kepada masyarakat.

Bagaimanakah hubungan hukum antara pasien dengan Tenaga Medis (dokter) dalam pelayanan kesehatan? Tujuan penelitian yaitu untuk mengetahui dan mempelajari hubungan hukum antara pasien dengan Tenaga Medis (dokter) dalam

*) Dosen Fakultas Hukum Universitas Galuh 
memberikan pelayanan kesehatan. Kegunaan penelitian diharapkan dapat menambah pengetahuan, khususnya yang berhubungan dengan materi Hukum Kesehatan, Hukum Perjanjian, dan Hukum Perlindungan Konsumen.

Metode penelitian yaitu dengan menggunakan pendekatan yuridis normatif yaitu mengkaji berbagai norma-norma aturan atau peraturan perundang-undangan yang berhubungan dengan objek penelitian tentang hubungan hukum antara pasien dengan Tenaga Medis (dokter) dalam pelayanan kesehatan.

Hubungan dokter dengan pasien timbul karena persetujuan untuk melakukan sesuatu bagi dokter untuk bersedia berusaha sesuai kemampuannya (semaksimal mungkin) untuk memenuhi perjanjian itu yakni merawat dan berusaha sesuai dengan standar profesi medik sedangkan pasien berkewajiban untuk memberikan imbalannya.

Tegasnya bahwa hubungan dokter dengan pasien diperlukan karena dengan adanya persetujuan berakibat telah tercapainya ikatan perjanjian yang menimbulkan hak dan kewajiban secara timbal balik, sehingga perjanjian mempunyai kekuatan mengikat artinya mempunyai kekuatan hukum yang dipatuhi oleh kedua belah pihak. Kata kunci: Pasien, Tenaga Medis (dokter), Hubungan hukumnya.

\section{PENDAHULUAN}

Masyarakat semakin menyadari hak-haknya sebagai konsumen kesehatan. Seringkali mereka mempertanyakan tentang penyakit, pemeriksaan, pengobatan, serta tindakan yang akan diambil berkenaan dengan penyakitnya. Hak-hak konsumen kesehatan masih cenderung sering dikalahkan oleh kekuasaan pemberi pelayanan kesehatan, kekalahan tersebut bisa berupa kerugian moral dan material yang cukup besar Undang-Undang Republik Indonesia Nomor 8 Tahun 1999 Tentang Perlindungan Konsumen (UUPK) mempunyai 2 sasaran pokok, yaitu :

1. Memberdayakan konsumen dalam hubungannya dengan pelaku usaha (publik atau privat) barang dan atau jasa;

2. Mengembangkan sikap pelaku usaha yang jujur dan bertanggung jawab lalu pertanyaannya, apakah pasien dapat disebut sebagai konsumen, dan pemberi pelayanan kesehatan (dokter) sebagai pelaku usaha.

Pengertian konsumen dan pelaku usaha berdasarkan UUPK yaitu, Konsumen adalah setiap orang pemakai barang dan atau jasa yang tersedia dalam masyarakat, baik bagi kepentingan diri sendiri, keluarga, orang lain, maupun makhluk hidup lain dan tidak untuk diperdagangkan, sedangkan produk berupa barang, misalnya, obat-obatan, suplemen makanan, alat 
kesehatan, dan produk berupa jasa, misalnya: jasa pelayanan kesehatan yang diberikan oleh dokter, dokter gigi, jasa asuransi kesehatan Untuk mengetahui, apakah profesi pemberi pelayanan kesehatan (dokter) merupakan pelaku usaha atau bukan maka kita harus melihat Undang-Undang Republik Indonesia Nomor 36 Tahun 2009 Tentang Kesehatan.

Tenaga Kesehatan adalah setiap orang yang mengabdikan diri dalam bidang kesehatan serta memiliki pengetahuan dan atau ketrampilan melalui pendidikan di bidang kesehatan yang untuk jenis tertentu memerlukan kewenangan untuk melakukan upaya Kesehatan, sebagaimana diatur dalam PERMENKES RI Nomor: 290 /MENKES/PER/III/2008 tentang persetujuan tindakan medis sebelum melakukan suatu tindakan yang didahului oleh penjelasan-penjelasan yang menyangkut tindakan, resiko, yang akan dilakukan pada pasien. Pasien maupun keluarganya akan mencari pertolongan kepada petugas kesehatan. Undang-Undang Republik Indonesia Nomor 8 Tahun 1999 Tentang Perlindungan Konsumen Tentang Perlindungan Konsumen juga dapat diberlakukan pada bidang kesehatan Dengan berlakunya UUPK diharapkan posisi konsumen sejajar dengan pelaku usaha, anggapan bahwa konsumen merupakan raja tidak berlaku lagi mengingat antara konsumen dan pelaku usaha tidak hanya mempunyai hak namun juga memiiki kewajiban. Pasien sebenarnya merupkan faktor liveware. Pasien harus dipandang sebagai subyek yang memiliki pengaruh besar atas hasil akhir layanan bukan sekedar obyek.

Hak-hak pasien harus dipenuhi mengingat kepuasan pasien menjadi salah satu barometer mutu layanan sedangkan ketidakpuasan pasien dapat menjadi pangkal tuntutan hukum. Penandatanganan formulir atau lembar persetujuan tindakan medis mempunyai konsekuensi telah tercapai apa yang dinamakan "sepakat para pihak yang mengikatkan diri, terjadi perjanjian untuk melaksanakan tindakan medis". Pesetujuan ini mempunyai kekuatan mengikat dalam arti mempunyai kekuatan hukum, berarti dokter boleh menjalankan kewajibannya meberikan informasi dan memberikan hak kepada dokter untuk melakukan tindakan medis. Terdapat pasal-pasal dalam KUHP yang relevan dengan masalah tanggung jawab secara hukum pidana dan atau hukum Perdata . 
Untuk memfokuskan tulisan ini, maka yang menjadi rumusan masalah yakni bagaimanakah hubungan hukum antara Pasien dengan Tenaga Medis (dokter) dalam pelayanan kesehatan ?

\section{PEMBAHASAN}

\subsection{Hubungan hukum antara Pasien dengan Tenaga Medis (dokter) dalam memberikan pelayan kesehatan}

Hubungan hukum antara dokter dengan pasien telah terjadi sejak dahulu (zaman Yunani kuno), dokter sebagai seorang yang memberikan pengobatan terhadap orang yang membutuhkannya. Hubungan ini merupakan hubungan yang sangat pribadi karena didasarkan atas kepercayaan dari pasien terhadap dokter yang disebut dengan transaksi terapeutik.

Transaksi terapeutik adalah perjanjian antara dokter dan pasien berupa hubungan hukum yang melahirkan hak dan kewajiban kedua belah Pihak. Objek dari perjanjian ini adalah berupa upaya atau terapi untuk menyembukan pasien.

Hubungan hukum antara dokter dengan pasien ini berawal dari pola hubungan vertikal paternalistik seperti antara bapak dengan anak yang bertolak dari prinsip "father knows best" yang melahirkan hubungan yang bersifat paternalistik. Hubungan hukum timbul bila pasien menghubungi dokter karena ia merasa ada sesuatu yang dirasakannya membahayakan kesehatannya. Keadaan psikobiologisnya memberikan peringatan bahwa ia merasa sakit, dan dalam hal ini dokterlah yang dianggapnya mampu menolongnya dan memberikan bantuan pertolongan. Jadi, kedudukan dokter dianggap lebih tinggi oleh pasien dan peranannya lebih penting daripada pasien.

Hak-hak dokter sebagai pengemban profesi dapat dirumuskan sebagai berikut :

1. Hak memperoleh informasi yang selengkap-lengkapnya dan sejujurjujurnya dari pasien yang akan digunakannya bagi kepentingan diagnosis maupun terapeutik.

2. Hak atas imbalan jasa atau honorarium terhadap pelayanan yang diberikannya kepada pasien. 
3. Hak atas itikad baik dari pasien atau keluarganya dalam melaksanakan transaksi terapeutik.

4. Hak membela diri terhadap tuntutan atau gugatan pasien atas pelayanan kesehatan yang diberikannya.

5. Hak untuk memperoleh persetujuan tindakan medik dari pasien atau keluarganya.

Hak-hak tersebut di atas, dokter juga mempunyai kewajiban yang harus dilaksanakan yaitu sebagai berikut :

1. Kewajiban untuk memberikan pelayanan medis sesuai dengan standar profesi, yaitu dengan cara melakukan tindakan medis dalam suatu kasus yang konkret menurut ukuran tertentu yang didasarkan pada ilmu medis dan pengalaman.

2. Kewajiban untuk menghormati hak-hak pasien, antara lain rahasia atas kesehatan pasien bahkan setelah pasien meninggal dunia.

3. Kewajiban untuk memberikan informasi pada pasien dan/atau keluarganya tentang tindakan medis yang dilakukannya dan risiko yang mungkin terjadi akibat tindakan medis tersebut.

4. Kewajiban merujuk pasien untuk berobat ke dokter lain yang mempunyai keahlian/kemampuan yang lebih baik.

5. Kewajiban untuk memberikan pertolongan dalam keadaan darurat sebagai tugas perikemanusiaan.

\subsection{Tanggung Jawab Hukum Dokter Terhadap Pasien}

Dokter sebagai tenaga professional bertanggung jawab dalam setiap tindakan medis (dokter) yang dilakukan terhadap pasien. Dalam menjalankan tugas profesionalnya didasarkan pada niat baik yaitu berupaya dengan sungguh-sungguh berdasarkan pengetahuannya yang dilandasi dengan sumpah dokter, kode etik kedokteran dan standar profesinya untuk menyembuhkan atau menolong pasien. Antara lain adalah:

Tanggung Jawab Etis : terjadinya Wanprestasi atau perbuatan melawan hukum dari tindakan dokter, menurut Pasal 1426 KUH Perdata ganti rugi yang dapat dibebankan jika terjadi Wanprestasi adalah, Kerugian yang nyata-nyata diderita kreditur yang disebut dengan 
Damnun Emergens; Keuntungan yang seharusnya diperoleh yang disebut Lucrum Cegans.Pada asasnya bentuk dari ganti rugi yang lazim dipergunakan ialah uang, oleh karena menurut ahli-ahli hukum perdata maupun yurisprudensi, uang merupakan alat yang paling praktis, yang paling sedikit menimbulkan selisih dalam menyelesaikan suatu sengketa. Selain uang masih ada bentuk-bentuk lain yang diperlukan sebagai bentuk ganti rugi yaitu pemulihan keadaan semula (innatura) dan larangan untuk mengulangi. Keduanya ini kalau tidak ditepati dapat diperkuat dengan uang paksa. Jadi harus diingat bahwa uang paksa bukan merupakan bentuk atau wujud ganti rugi.

Gugatan untuk membayar ganti rugi atas dasar persetujuan atau perjanjian yang terjadi hanya dapat dilakukan bila memang ada perjanjian dokter dengan pasien. Perjanjian tersebut dapat digolongkan sebagai persetujuan untuk melakukan atau berbuat sesuatu. Perjanjian itu terjadi bila pasien memanggil dokter atau pergi ke dokter, dan dokter memenuhi permintaan pasien untuk mengobatinya. Dalam hal ini pasien akan membayar sejumlah uang. Sedangkan dokter sebenarnya harus melakukan prestasi menyembuhkan pasien dari penyakitnya. Tetapi penyembuhan itu tidak pasti selalu dapat dilakukan sehingga seorang dokter hanya mengikatkan dirinya. untuk memberikan bantuan sedapatdapatnya, sesuai dengan ilmu dan ketrampilan yang dikuasainya. Artinya, dia berjanji akan berdaya upaya sekuat-kuatnya untuk menyembuhkan pasien. Tanggung Jawab Perdata Dokter Karena Perbuatan Melanggar Hukum (onrechtmatige daad) berdasarkan Pasal 1365 KUH Perdata. Adanya tindakan atau perbuatan Unsur-unsur yang tersimpul dari perumusan Pasal 1365 adalah:

1. Perbuatan itu harus melawan hukum (onrecht matigedaad)

2. Pelakunya mempunyai unsur salah

3. Tindakan atau perbuatan itu menimbulkan kerugian.

Berdasarkan Pasal 1366 KUH Perdata, seorang dokter selain dapat dituntut atas dasar wanprestasi dan melanggar hukum seperti tersebut di atas, dapat pula dituntut atas dasar lalai, sehingga menimbulkan kerugian. Gugatan atas dasar kelalaian ini diatur dalam Pasal 1366 KUH Perdata, menyatakan : "Setiap orang bertanggung 
jawab tidak saja untuk kerugian yang disebabkan karena perbuatannya, tetapi juga untuk kerugian yang disebabkan karena kelalaian atau kurang hati-hatinya". Berdasarkan Pasal 1367 KUH Perdata, apabila kita simpulkan maka dari segi hukum perdata, tanggung jawab tersebut dapat mengandung beberapa aspek yaitu dapat ditimbulkan karena "wanprestasi" (tidak memenuhi prestasi), karena perbuatan melanggar hukum (onrecht matigedaad), dapat juga karena kurang hati-hatinya mengakibatkan matinya orang (moedwillige/onrecht matigedoodslag) dan juga karena kurang hati-hatinya mengakibatkan cacat badan.

\subsection{Hubungan Hukum Dokter Dengan Pasien}

Hubungan hukum dokter-pasien akan menempatkan dokter dan pasien berada pada kesejajaran, sehingga setiap apa yang dilakukan oleh dokter terhadap pasien tersebut harus melibatkan pasien dalam menentukan apakah sesuatu tersebut dapat atau tidak dapat dilakukan atas dirinya. Salah satu bentuk kesejajaran dalam hubugan hukum dokter pasien adalah melalui informed consent atau persetujuan tindakan medik. Pasien berhak memutuskan apakah menerima atau menolak sebagian atau seluruhnya rencana tindakan dan pengobatan yang akan dilakukan oleh dokter terhadap dirinya. Undang-Undang Republik Indonesia Nomor 29 Tahun 2004 Tentang Praktik Kedokteran, khusunya mengatur tentang Hak dan Kewajiban Dokter atau tenaga medis, doktcr mempunyai hak :

1. memperoleh perlindungan hukum sepanjang melaksanakan tugas sesuai dengan standar profesi dan standar prosedur operasional;

2. memberikan pelayanan medis menurut standar profesi dan standar prosedur operasional;

3. memperoleh informasi yang iengkap dan jujur dan pasien atau keluarganya;

4. menerima imbalan jasa.

Hubungan hukum dokter pasien yang sesuai Pasal 1320 KUHPerdata yang mengatur syarat-syarat sahnya sebuah perjajiajan atau perikatan hukum Syarat-syarat tersebut yaitu antara lain : 
1. Pelaku perjanjian harus dapat bertindak sebagai subjek hukum.

2. Perjanjian antara subjek hukum tersebut harus atas dasar sukarela dan tanpa paksaan.

3. Perjanjian tersebut memperjanjikan sesuatu di bidang pelayanan kesehatan.

4. Perjanjian tersebut harus atas sebab yang halal dan tidak bertentangan dengan hukum.

Hubungan hukum rumah sakit-pasien adalah sebuah hubungan perdata yang menekankan pelaksanaan hak-hak dan kewajibankewajiban masing-masing pihak secara timbal balik. Dokter berkewajiban untuk memenuhi hak-hak pasien dan sebaliknya pasien berkewajiban memenuhi hak dokter. Kegagalan salah satu pihak memenuhi hak-hak pihak lain, apakah karena wanprestasi atau kelalaian akan berakibat pada gugatan atau tuntutan perdata yang berupa ganti rugi atas kerugian yang dialami oleh pasien.

Dalam hubungan antara dokter dan pasien sering timbul masalah dengan adanya dugaan terjadinya kelalaian medis, hal itu dapat juga disebabkan karena kurangnya pemahaman atau persepsi yang sama atas hak dan kewajiban baik pemberi dan penerima pelayanan kesehatan. Masalah hukum yang timbul tersebut dapat diakibatkan kesalahan atau kelalaian para petugas kesehatan atau diakibatkan kesalahan dalam menerapkan kebijaksanaan atas peraturan dan juga diakibatkan kekurangan pengetahuan para petugas tentang Hukum Kesehatan atau peraturan perundangundangan dibidang kesehatan. Perkembangan saat ini masyarakat semakin sadar atas hak-haknya yang secara otomatis menuntut adanya transparansi pelayanan kesehatan, terutama dalam kaitan hubungan dokter dengan pasien dan menyangkut keluhan yang dialami pasien serta terapi, pengobatan yang dilakukan oleh dokter terhadap pasien. Hal yang sangat mendasar dalam pelayanan kesehatan yang selalu dipermasalahkan masyarakat, pasien adalah menyangkut keterbukaan, transparansi, mutu pelayanan, penerapan aturan, kedisiplinan waktu, sehingga sering diduga melakukan kelalaian medis atau musibah klinis. 
Dalam hal ini, rumah sakit harus dapat memberikan perlindungan dan kepastian hukum bagi seluruh tenaga kesehatan yang memberikan pelayanan kesehatan melalui pembentukan berbagai perangkat aturan meliputi, peraturan internal staf medis, standar prosedur operasional dan berbagai pedoman pelayanan kesehatan serta melalui penyediaan SDM yang memiliki kompetensi dalam bidang medikolegal. Hal lain yang perlu mendapat perhatian bersama oleh seluruh pihak di rumah sakit adalah menyangkut pelaksanaan etika profesi dan etika rumah sakit sehingga penyelenggaraan Pelayanan secara beretika akan sangat mempermudah seluruh pihak dalam menegakkan aturan-aturan hukum.

Permasalahan hukum yang dihadapi tenaga medis atau dokter dalam pelayanan medis. Adapun dalam suatu sistem kesehatan, interaksi yang nampak adalah interaksi antara dokter dan pasien yang mungkin juga melibatkan unsur-unsur lainnya. Unsur-unsur lain tersebut mungkin para medis baik bagian perawatan maupun non perawatan, pekerja sosial dan rumah sakit, di mana mereka secara pribadi atau bersama-sama terikat oleh kaidah-kaidah tertentu, baik kaidah-kaidah hukum maupun kaidah sosial lainnya. Sistem kesehatan adalah profesi kedokteran, karena menurut anggapan umum, seseorang yang mempunyai profesi ini adalah menyenangkan, yaitu dianggap merupakan profesi yang mulia. Oleh karena itu perlunya ditinjau kembali Perangkat hukum yang mengatur penyelenggaraan praktik kedokteran dirasakan belum memadai, selama ini masih didominasi oleh kebutuhan formal dan kepentingan pemerintah,sedangkan porsi profesi masih sangat kurang. Dokter dengan perangkat keilmuan yang dimilkinya mempuyai karakteristik yang khas. Kekhasannya ini terlihat dari pembenaran yang diberikan oleh hukum yaitu diperkenankannya melakukan tindakan medik terhadap tubuh manusia dalam upaya memelihara dan meningkatkan derajat kesehatan.

\section{KESIMPULAN DAN SARAN}

\subsection{Kesimpulan}

Hubungan hukum antara pasien dengan tenaga medis dalam memberikan pelayanan kesehatan yaitu bersumber pada kepercayaan pasien terhadap tenaga medis (dokter atau perawat) sehingga pasien bersedia memberikan persetujuan tindakan medis (informed consent), 
yaitu suatu persetujuan pasien untuk menerima upaya medis yang akan dilakukan terhadapnya. Hal ini dilakukan setelah ia mendapat informasi dari dokter mengenai upaya medis yang dapat dilakukan untuk menolong dirinya, termasuk memperoleh informasi mengenai segala risiko yang mungkin terjadi. Adapun di Indonesia informed consent dalam pelayanan kesehatan, telah memperoleh pembenaran secara yuridis melalui Peraturan Menteri Kesehatan Republik Indonesia Nomor 290/MENKES/PER/III/2008. Hubungan tersebut lahir dan memenuhi syarat sahnya transaksi terapeutik didasarkan Pasal 1320 KUH Perdata Yaitu, syarat subyektif dan syarat obyektif.

\subsection{Saran}

Bahwa disarankan agar segala sesuatu yang dilakukan oleh dokter terhadap pasiennya dalam upaya penyembuhan penyakit pasien adalah merupakan perbuatan hukum yang kepadanya dapat dimintai petanggung jawaban hukum, dituntut profesionalisme, memberikan pelayanan medik adalah sebuah perbuatan hukum. Hanyalah tindakan profesional kedokteran harus sesuai dengan kode etik profesional dan sumpah jabatan dokter.

\section{DAFTAR PUSTAKA}

\section{A. Buku-buku}

Fuady Munir, 2005, Hukum Bisnis dalam Teori dan Praktek, Bandung, PT. Citra Aditya.

Gunawan, J, 1995, Persetujuan Tindakan Medis (Informed Consent), Jakarta, FK. Ul. Ul. 2004, Hukum Medik, Cetakan Pertama, Jakarta, Balai Penerbit FK. 2005, Informed Consent dan Rekam Medis, Jakarta.

Haryani, Syafitri, 2005, Sengketa Medis: Alternatif Penyelesaian antara Dokter dengan Pasien, Jakarta, Diadit Media.

Kancil, CST, 1991, Pengantar Hukum Kesehatan Indonesia, Jakarta, Rineka Cipta.

Kusumah Astuti, Endang, 2003, Hubungan Antara Dokter dan Pasien Dalam Upaya Pelayanan Medis, Semarang. 
Nasution, Barder Johan, 2008, Hukum Kesehatan, Pertanggungjawaban Dokter, Jakarta, Rineka Cipta.

Satrio, J, 1993, Hukum Perikatan, Bandung, PT. Citra Aditya Bakti.

Subekti, R. dan R. Tjitrosudibio, 2002, Kitab Undang-Undang Hukum Perdata, Jakarta, PT Pradnya Paramita.

Suparman, Eman, 2005, Tanggung Jawab Hukum dan Etika Profesi Tenaga Kesehatan, Malang.

\section{B. Perundang-Undangan}

Undang-Undang Republik Indonesia Nomor 8 Tahun 1999 Tentang Perlindungan Konsumen.

Undang-Undang Republik Indonesia Nomor 29 Tahun 2004 Tentang Praktik Kedokteran.

Undang-Undang Republik Indonesia Nomor 36 Tahun 2009 Tentang Kesehatan.

Peraturan Menteri Kesehatan Republik Indonesia Nomor 290/ MENKES/PER/III/ 2018 Tentang Persetujuan Tindakan Kedokteran. 